\title{
Chronology of Meiosis and Spermiogenesis in an Indian Catfish, Heteropneustes fossilis (Bloch)*
}

By

\section{TIMIR K. BANDYOPADHAY}

Zoology Department, S.B. College, Magra, Hooghly, WB 712 148, India

And

SUDHANGSU K. GHOSAL

Zoology Department, Burdwan University, Burdwan WB 713 104, India

-Received for Publication, August 24, 1984 -

Key Words : Catfish, duration, meiosis, spermiogenesis

Summary: The duration of various stages of meiosis and spermiogenesis of Heteropneustes fossilis was calculated by following the kinetics of ${ }^{3} \mathbf{H}$-thymidine labelled spermatocytes autoradiographically. Leptotene lasts less than 12 hours. The duration of pachytene is between 1.94 and 2.20 days. The individual duration of zygotene as well as that of stages from diplotene to metaphase-II is extremely short. Meiosis is completed within 3.34 days whereas spermiogenesis never spans more than 8.50 days. The total duration of meiosis and spermiogenesis does not exceed 11.50 days.

The duration of meiosis and spermiogenesis in vertebrates is specific for a particular species (Clermont and Trott, 1969; Roosen-Runge, 1977). Despite a huge accumulation of data on mammalian spermatogenesis (Heller and Clermont, 1963; Clermont and Harvey, 1965; Utakoji, 1966; Ghosal and Mukherjee, 1971; Swierstra et al., 1974), very little information is available on the duration of spermatogenesis in fishes (DeFelice and Rash, 1969; Sinha et al., 1979). The present autoradiographic investigation was designed to estimate the duration of stages of meiosis and spermiogenesis in a silurid fish, Heteropneustes fossilis.

\section{Materials and Methods}

Twenty-five mature male Heteropneustes fossilis (Bloch), body weight 100 to $150 \mathrm{~g}$, were purchased from local fish markets in the months of June and July during their breeding season. Each fish was injected intraperitoneally with $20 \mu \mathrm{Ci}$ of ${ }^{3} \mathrm{H}$-thymidine (Smp. act. 10,600 mCi/mM, BARC Bombay). Fishes were kept in an aquarium $\left(25^{\circ} \pm 1^{\circ} \mathrm{C}\right)$ and were sacrificed at intervals between $2 \mathrm{~h}$ and $22 \mathrm{~d}$ after the administration of the isotope (Table 1). Testes were minced in normal saline and fixed in freshly prepared $3: 1$ alcohol/acetic acid (30 $\mathrm{min})$ for both squash and air dry preparations (Mukherjee

* Dedicated to Professor N. Egami in recognition of his contribution to piscine spermatogenesis 
Table. 1. Most advanced labelled stages of meiosis and spemiogenesis detected at various intervals following the injection of ${ }^{3} \mathrm{H}$-thymidine

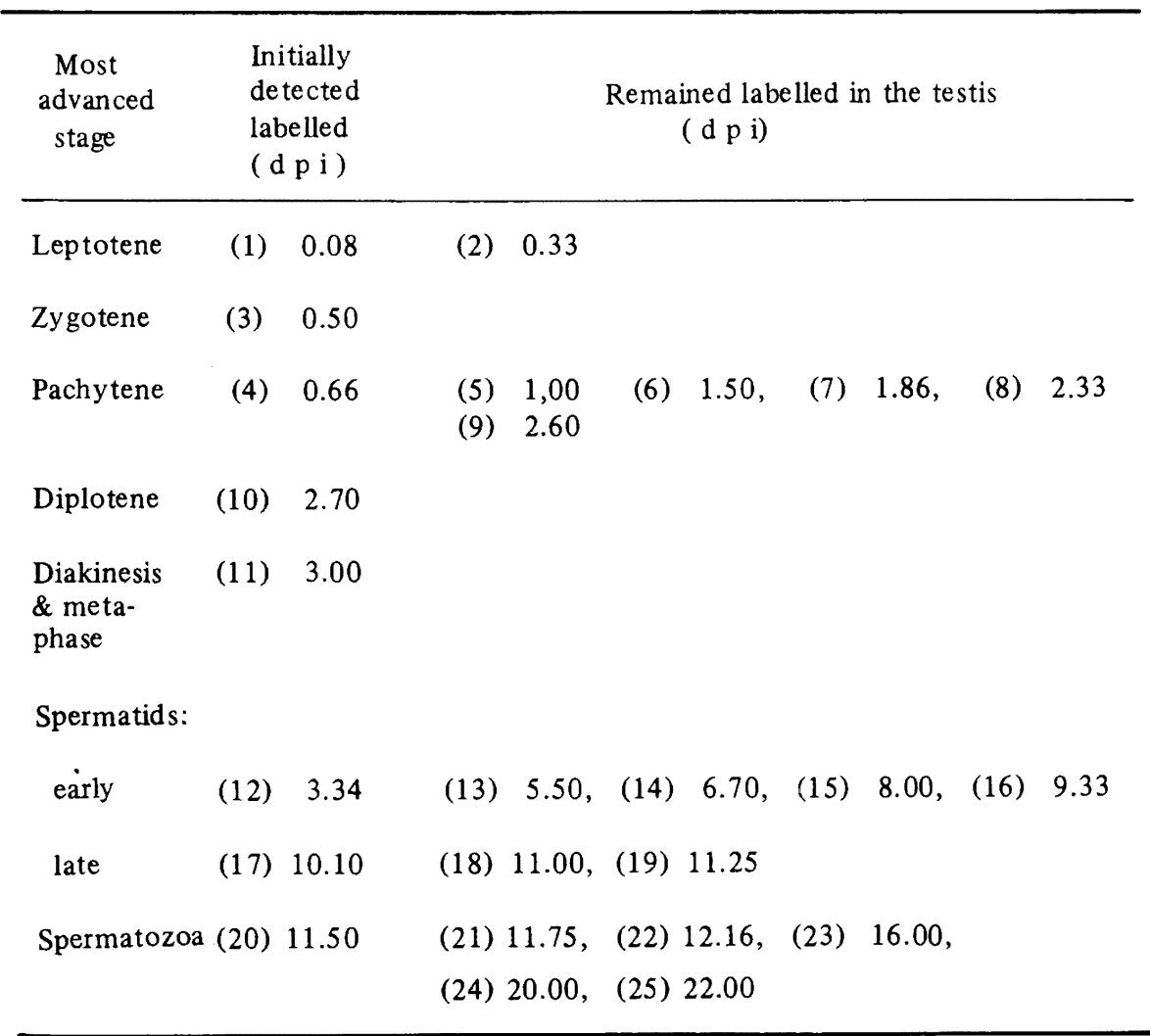

Serial number of fishes killed is within parenthesis. At least 260 labelled "most advanced meiotic stage" or "stage of developing spermatids" were counted from each fish.

and Ghosal, 1969). The cells were stained with Giemsa and slides were autoradiographed with Kodak AR-10 stripping film. The course of migration of labelled spermatocytes through stages of meiosis and spermiogenesis was followed and the duration of individual stages calculated by conventional methods (DeFelice and Rasch, 1969; Ghosal and Mukherjee, 1971; Kalt, 1976; Sinha et al., 1979).

\section{Results}

Leptotene was the only labelled meiotic stage (Plate I, Fig. 1) in the testicular tissue of the first fish sacrificed at 0.08 day $(2 \mathrm{~h})$ post-injection. Leptotene spermatocytes were also found labelled in the next fish killed at 0.33 day post-injection ( $\mathrm{d} p \mathrm{i}$ ) whereas zygotene figures (Fig. 2) appear for the first time at $0.50 \mathrm{~d} \mathrm{p}$ i. This suggests that the duration of leptotene is greater than 0.33 day, but less than 0.50 day. The duration of zygotene appears to be much shorter since labelled pachytenes (Fig. 3) were detected for the first time at $0.66 \mathrm{~d}$ post-injection. Pachytenes remained radioactive upto $2.60 \mathrm{~d}$ p i (Table 1). However, diplotene (Fig. 4) was found labelled in the testis of fish sacrificed at $2.70 \mathrm{~d}$. Although it was not possible to pinpoint the exact initiation and termination of any meiotic stage, it could be 
said with certainty that any time between $0.33 \mathrm{~d}$ and $0.50 \mathrm{~d}$ following the injection of ${ }^{3} \mathrm{H}$-thmidine zygotene spermatocytes reached the pachytene stage and also that any time between 2.50 and $2.70 \mathrm{~d}$ p i pachytene passed to the next stage. One may then infer that the duration of pachytene can be neither less than 1.94 days, nor more than 2.20 days. It was interesting to observe that diakinesis, metaphase-I and metaphase-II were scored radioactive for the first time in the same fish killed at $3.00 \mathrm{~d}$ while early spermatids were the most advanced labelled germline cells in the tissues obtained from the next fish at $3.34 \mathrm{~d} \mathrm{p}$ i. We conclude that the spermatocytes, which had been at pachytene stage at $2.60 \mathrm{~d}$, passed very rapidly through stages from diplotene to metaphase-II and finally became spermatids at 3.34 day. In fact, all these successions occurred within 18 hours. This not only suggests that the duration of diplotene, diakinesis, metaphase-I and metaphase-II is exceedingly short, but also that meiosis is completed in this species within 3.34 days. After their labelled appearance at $3.34 \mathrm{~d} p$ i, early spermatids (Fig. 6), easily distinguished by their spherical shape remained the most highly progressed labelled product of spermatocytes until $9.33 \mathrm{~d}$ whereas at $10.10 \mathrm{~d}$ they assumed an oblong shape and were termed late spermatids. Further elongation, as well as concurrent flattening of the head, was noted at 11.25 day. Radioactive spermatozoa (Fig. 7) were initially detected in the next fish that had been killed at 11.50 $\mathrm{d}$. We therefore suggest that the duration of spermiogenesis is between 8.50 and 7.91 days. Both meiosis and spermiogenesis in this fish are completed by 11.50 days.

\section{Discussion}

Although the duration of spermatogenesis has been investigated in great detail in seve- ral mammals, viz, man (Heller and Clermont, 1963), stallion (Swierstra et al., 1974), mouse (Ghosal and Mukherjee, 1971), guinea pig (Noller et al., 1977) and hamster (Utakoji, 1966; Ghosal and Mukherjee, 1971) using autoradiographic techniques, our present knowledge of the chronology of piscine spermatogenesis is meagre. Egami and Hyodo-Taguchi (1967) have reported that the duration of spermatogenesis is 12 days (at $25^{\circ} \mathrm{C}$ ) in the teleost Oryzias latipes. Unlike other workers (Egami and HyodoTaguchi, 1967; DeFelice and Rasch, 1969) who calculated the duration of meiosis as a whole (Table 2), Sinha et al. (1979) attempted to estimate the individual duration of meiotic stages and this was achieved by sacrificing fishes at shorter intervals. Similar shorter intervals were also maintained during the present investigation on Heteropneustes fossilis. Radioactive leptotenes were detected in the first fish that had been sacrificed as early as 2 hours after the administration of isotope. Therefore, it seems that spermatocytes enter the leptotene stage immediately after synthesizing their DNA. Investigators working on other vertebrates, e.g., Xenopus laevis (Kalt, 1976), Calotes versicolor (Bandyopadhyay, 1977), pigeon (Joardar and Ghosal, 1977), mouse (Clermont and Trott, 1969), man (Heller and Clermont, 1963), etc. reported the same phenomenon and have suggested that any post-DNA synthesis gap, comparable to the $\mathrm{G}_{2}$ period of mitotic cells (Mukherjee and Ghosal, 1969), is absent in vertebrate spermatocytes.

The durations of meiosis and spermiogenesis in Heteropneustes fossilis do not exceed 3.34 and 8.5 days respectively. Table 2 records the duration of meiosis and spermiogenesis in several fishes and mammals for the sake of comparison. In contrast to mammals, the shorter duration of spermatogenesis in teleosts may be correlated 
Table 2. Duration (in days) of meiosis and spermiogenesis in a few fishes and mammals

\begin{tabular}{lllllll}
\hline Lepto & Zygo & Pachy & D-M & Meiosis & Sprmio & Total References \\
\hline
\end{tabular}

(A) FISHES (Teleosts):

\begin{tabular}{|c|c|c|c|c|c|c|c|c|}
\hline Colisa fasciata & 0.4 & 0.1 & 2.6 & 0.8 & 3.9 & 6.0 & 9.9 & Sinha et al. (1979) \\
\hline Anabas testudineus & 0.5 & 0.2 & 2.3 & 0.8 & 3.8 & 6.7 & 10.5 & Sinha et al. (1982) \\
\hline Channa punctatus & 0.4 & 0.1 & 2.1 & 0.8 & 3.4 & 8.0 & 11.4 & Sinha et al. (1983) \\
\hline Poecilia sphenops & - & - & - & - & 3.0 & 18.0 & 21.0 & $\begin{array}{l}\text { DeFelice and } \\
\text { Rasch (1969) }\end{array}$ \\
\hline Oryzias latipes & - & - & - & - & 5.0 & 7.0 & 12.0 & $\begin{array}{c}\text { Egami and Hyodo- } \\
\text { Taguchi (1967) }\end{array}$ \\
\hline
\end{tabular}

(B) MAMMALS

\begin{tabular}{lcccccccc} 
Mouse & 2.6 & 0.7 & 7.4 & 0.8 & 11.4 & 15.4 & 26.8 & $\begin{array}{l}\text { Ghosal and } \\
\text { Mukherjee (1971) }\end{array}$ \\
Golden hamster & 2.5 & 0.6 & 7.2 & 0.5 & 11.0 & 14.8 & 25.8 & $\begin{array}{l}\text { do }- \\
\text { Cat }\end{array}$ \\
& 3.8 & 0.5 & 15.0 & 0.8 & 20.1 & 20.2 & 41.3 & $\begin{array}{c}\text { Ghosal and } \\
\text { Midya (in press) }\end{array}$ \\
Dog & 4.2 & 0.8 & 15.5 & 1.8 & 22.3 & 19.8 & 42.1 & $\begin{array}{c}\text { Ghosal } \text { et al. (1974) } \\
\text { Stallion }\end{array}$ \\
Man & 3.2 & 0.5 & 11.7 & 0.8 & 16.2 & 18.8 & 35.0 & $\begin{array}{c}\text { Swierstra } \text { et al. (1974) } \\
\text { Heller and Clermont } \\
\text { (1963) }\end{array}$ \\
\hline
\end{tabular}

Abbreviations : $\quad \mathrm{D}-\mathrm{M}=$ Diplotene to metaphase-II, Sprmio $=$ Spermiogenesis, Total $=$ The total duration of meiosis and spermiogenesis.

with the annual reproduction cycle (RoosenRunge, 1977) particularly in the majority of freshwater teleosts (Bhatti and Al-Daham, 1978) in which the breeding season is confined to a maximum of three months in a year.

\section{Acknowledgement}

We are thankful to Professors B.B. Mukherjee (McGill University), F.C. Fraser (Memorial University of Newfoundland) and Y. Clermont (McGill University) for encouragement, Emeritus Professor R.W. Pickford (University of Glasgow) for donating Kodak stripping film, Professors G.K. Manna
(Kalyani University), Professor G. Yasuzumi, Hanwa Memorial Hospital, Osaka City and Dr. T. Utakoji (Tokyo Cancer Institute) for interest. This work was funded by Indian CSIR 38 (395)/81-EMR-II and UGC F.23$348 / 75$ (SR-II) grants to SKG.

\section{References}

1) Bandyopadhyay, T.K. : The chronology of meiosis and spermiogenesis in Heteropneustes fossilis, Bufo melanostictus, Calotes versicolor and Bos indicus. Ph. D. thesis, 1977: Burdwan University, Burdwan.

2) Bhatti, M.Z. and Al-Daham, N.K. : Annual cyclical changes in testicular activity of a freshwater teleost, Barbus luteus (Heckel) from Shatt-Al-Arab, Iraq. J. Fish Biol., 13 : 
$321-326,1978$.

3) Clermont, Y. and Trott, B. : Duration of the cycle of the seminiferous epithelium in the mouse and hamster determined by means of ${ }^{3} \mathrm{H}$-thymidine and radioautography. Fertil. Steril. 20, 805-817, 1969.

4) Clermont, Y. and Harvey, S.C. : Duration of the cycle of the seminiferous epithelim of normal, hypophysectomized and hypophysectomized-hormone treated albino rats. Endrocrinology, 76, 80-98, 1965.

5) DeFelice, D.A. and Rasch, E.M.: Chronology of spermatogenesis and spermiogenesis in Poecilid fishes. J. Exp. Zool., 171, 191-204, 1969.

6) Egami, N. and Hyodo-Taguchi, V. : An autoradiographic examination of the rate of spermatogenesis at different temperatures in the fish, Oryzias latipes. Exp. Cell Res., 47, 663-667, 1967.

7) Ghosal, S.K. and Mukherjee, B.B. : The chronology of DNA synthesis, meiosis and spermiogenesis in the male mouse and golden hamster. Can. J. Genet. Cytol., 13, 672$682,1971$.

8) Ghosal, S.K., LaMarche, P.H., Bhanja, P., Joardar, S., Sengupta, A. and Midya, T. : Duration of meiosis and spermiogenesis in the dog. Can. J. Genet. Cy tol., 25, 678-681, 1983.

9) Ghosal, S.K. and Midya, T : Autoradiographic studies on the chronology of meiosis and spermiogenesis in the cat. Cytologia, 49, 823-831, 1984 .

10) Heller, C.G. and Clermont, Y. : Spermatogenesis in man : an estimate of its duration. Science, $140,184-186,1963$.

11) Joardar, S. and Ghosal, S.K. : Spermatogenesis in the pigeon. Proc. First Internatl.
Symp. Avian Endocrionol., Calcutta, 1, 75, 1977.

12) Kalt, M.R. : Morphology and kinetics of spermatogenesis in Xenopus laevis. J. Exp. Zool., 195, 393-408, 1976.

13) Mukherjee, B.B. and Ghosal, S.K. : Replicative differentiation of mammalian sex chromosomes during spermatogenesis. Exp. Cell Res., 54, 101-106, 1969.

14) Noller, D.W., Howard, S.S. and Flickinger, C.J. : Duration of the seminiferous epithelium cyclen the mature guinea pig : influence of unilateral orchiectomy. Fertil. Steril., 28, 998-1002, 1977.

15) Roosen-Runge, E.C. : The process of spermatogenesis in animals. 380 pp. Cambridge : Cambridge University Press, 1977.

16) Sinha, G.M., Mondal, S.K., Midya, T. and Ghosal, S.K. : Chronology of meiosis and spermiogenesis in a freshwater teleost fish, Colisa fasciata (Block \& Schneider). Z. mikrosk.-anat. Forsch. Leipzig., 93, 442-449, 1979.

17) Sinha, G.M., Mondal, S.K. and Ghosal, S.K.: Autoradiographic studies on the chronology of meiosis and spermiogenesis in a freshwater teleost, Anabas testudieneus (Bloch). Cytologia, 47, 309-315, 1982.

18) Sinha, G.M., Mondal, S.K. and Ghosal, S.K. : Meiosis and spermiogenesis in a fresh water teleost fish, Channa punctatus (Bloch) : An estimation of their duration by autoradiographic method. Cy tologia, 48, 87-93, 1983.

19) Swierstra, E.E., Gebaur, M.R. and Pickett, B.W. : Reproductive physiology of the stallion. I. Spermatogenesis and testes composition. J. Reprod. Fertil., 40, 113-123, 1974.

20) Utakoji, T. : Chronology of nucleic acid synthesis in the male Chinese hamster. Exp. Cell Res., 42, 585-596, 1966. 


\section{Explanation of Figure}

\section{Plate I}

Photomicrographs of autoradiograms of labelled stages of meiosis and spermiogenesis detected in the testis of Heteropneustes fossilis following the injection of ${ }^{3} \mathrm{H}$-thymidine.

Fig. 1. Labelled leptotene spermatocy tes observed in the first fish killed at $0.08 \mathrm{~d}$. Air dry preparation $(\times 1000)$.

Fig. 2. Radioactive zygotene stages detected for the first time at $0.50 \mathrm{dp}$ i. Squash preparation $(\times 1000)$.

Fig. 3. A pachytene spermatocyte found labelled at 0.66 day. Air dry preparation $(\times 1600)$.

Fig. 4. Labelled diplotene stage obtained at 2.70 d. Air dry preparation $(\times 1600)$.

Fig. 5. A radioactive early diakinesis $(3.00 \mathrm{~d})$. Air dry preparation $(\times 1000)$.

Fig. 6. Labelled early (round) spermatids detected for the first time at $3.34 \mathrm{~d}$ Post-injection. Squash prepation $(\times 1200)$.

Fig. 7. Labelled spermatozoa (mostly in the form of bundles) observed for the first time in the testis of fish sacrificed at $11.50 \mathrm{~d}$. Squash preparation $(\times 1500)$. 


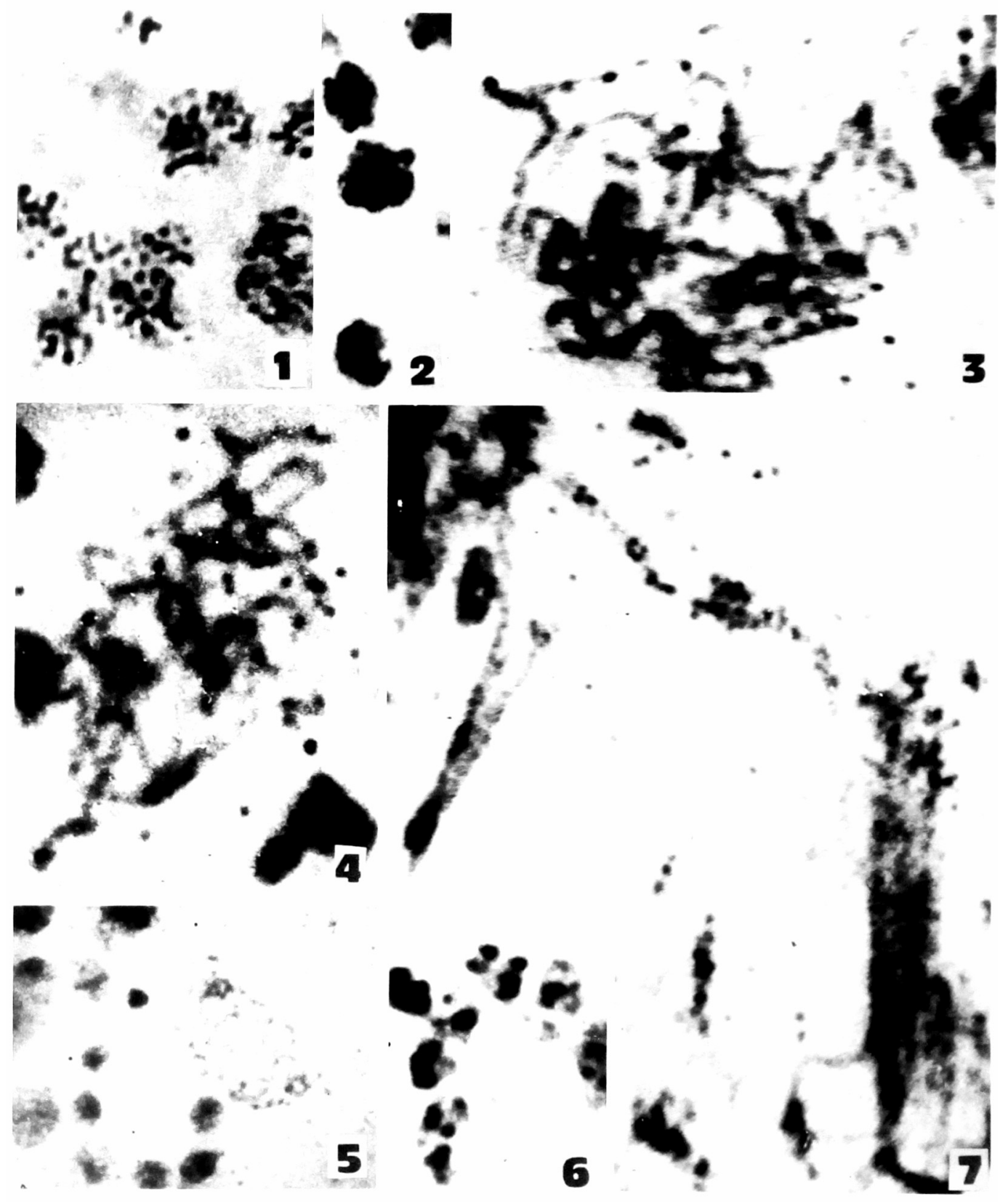

